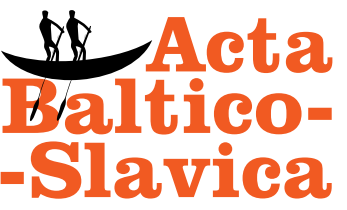

Acta Baltico-Slavica, 38 SOW, Warszawa 2014

DOI: $10.11649 /$ abs.2014.013

\author{
Katarzyna Konczewska \\ Grodno \\ kaskon1973@gmail.com
}

\title{
Uwagi o polszczyźnie inskrypcji nagrobnych na Grodzieńszczyźnie ${ }^{1}$
}

W latach 2010-2013 prowadziłam na Grodzieńszczyźnie badania, których przedmiotem było określenie aktualnej dystrybucji języka polskiego. Podczas eksploracji odwiedzałam także cmentarze, przede wszystkim we wsiach i w dawnych miasteczkach, poszukując napisów nagrobnych w języku polskim. Wiaczesław Werenicz, prekursor rozpoczętych w latach 80 . XX w. badań nad językiem polskich inskrypcji nagrobnych na Białorusi, zwracał uwagę na to, że analiza inskrypcji ma szczególne znaczenie w badaniach na terenach zamieszkanych przez ludność mieszaną (Werenicz, 2001, s. 169), podkreślając, że jest ona bardzo pomocna do zobrazowania dawnej i współczesnej sytuacji etnosocjologicznej regionu (Werenicz, 2001, s. 182). Badania inskrypcji nagrobnych na Grodzieńszczyźnie uważam za szczególnie ważne i ciekawe, ponieważ są one nie tylko świadectwem wielokulturowości Wielkiego Księstwa Litewskiego i Rzeczypospolitej Obojga Narodów, ale niosą też niezwykle istotne informacje historyczno-językowe i tożsamościowe, pozwalają na poznanie sytuacji etniczno-językowej, odzwierciedlają żywą mowę ludności zamieszkującej ten teren.

1 Niniejszy artykuł jest rozszerzoną i poprawioną wersją tekstu opublikowanego w: Bednarczuk L., Chodurska H., Mażulis-Frydel A. (red.), Polono-Slavica in honorem Maria Wojtyła-Świerzowska, W-wo Impuls, Kraków 2014, s. 127-139.

This is an Open Access article distributed under the terms of the Creative Commons Attribution 3.0 PL License (creativecommons.org/licenses/by/3.0/pl/), which permits redistribution, commercial and non-commercial, provided that the article is properly cited. (C) The Author(s) 2014. 
Polskie inskrypcje na cmentarzach Białorusi nieczęsto były przedmiotem opisu. Jadwiga Kozłowska-Doda opracowała język inskrypcji Białorusi środkowej (Dzierżyńszczyzna) i pogranicza białorusko-litewskiego (Дода, 1997, ss. 34-36; Kozłowska-Doda, 2000, s. 109). Irena Maryniakowa (2001, ss. 241-246) opisała język inskrypcji nagrobnych w powiecie widzkim (północno-zachodnie Pojezierze Białoruskie) i postawskim (Białoruś północno-zachodnia). Anna Stelmaczonek (2002, ss. 87-92) przedstawiła język napisów na cmentarzach parafii dryświackiej koło Brasławia (pogranicze białorusko-litewsko-łotewskie). Ukazały się także: publikacje Dagnosława Demskiego o białoruskich cmentarzach wiejskich (2000) i Anny Łukuć o cmentarzach parafii Teolin-Sopoćkinie na pograniczu białorusko-litewsko-polskim (2011, ss. 107-11); monografia Jacka Rozmusa i Jerzego Gordziejewa o cmentarzu farnym w Grodnie (1999) i opracowania zespołu autorów - Anny Lewkowskiej, Wojciecha Walczaka i Jacka Lewkowskiego o zabytkowych cmentarzach na Kresach Wschodnich Drugiej Rzeczypospolitej (prace o cmentarzach na terenie dzisiejszej Białorusi opublikowano w roku 2007). Zawierają one przede wszystkim opisy badanych cmentarzy, analizują ich epigrafikę i symbolikę sakralną, omawiają kwestie obrazowania (symbole religijne, konwencje modlitewne).

Z przedstawionego w skrócie stanu badań wynika, że do tej pory nie prowadzono szerzej zakrojonych lingwistycznych eksploracji polskich inskrypcji nagrobnych. Dotychczas opisana została wybiórczo tylko nieznaczna część cmentarzy na Białorusi środkowej i północno-zachodniej. Wiaczesław Werenicz inwentaryzował napisy nagrobkowe na cmentarzach w Postawach i Brasławiu, jednak ich nie systematyzował (Werenicz, 2001, s. 170).

Celem mojego artykułu jest ukazanie i próba analizy regionalnych cech języka odzwierciedlonych w inskrypcjach nagrobnych cmentarzy na Grodzieńszczyźnie. Dlatego też pomijam tu szczegółowe opisy, klasyfikację zinwentaryzowanych napisów oraz problematykę antropotanatologiczną.

Jako materiał badawczy posłużą mi napisy umieszczone w obrębie mogiły: na krzyżu, pomniku nagrobnym lub płycie, powstałe po II wojnie światowej, pisane tylko po polsku i dodatkowo zawierające cechy polszczyzny północnokresowej. Wybór ram czasowych (od końca lat 40. XX w. po ostatnie z roku 2013 został podyktowany zmianami sytuacji historycznej i socjolingwistycznej na badanych terenach. Materiał pochodzi z siedmiu miejscowości (Kwasówka, Indura, Wierejki, Repla, Łunna, Wołpa, Roś), położonych na południe i południowy wschód od Grodna wzdłuż polskiej granicy, w których także współcześnie notowano mowę polską (Grek-Pabisowa, 2002, s. 155).

Należące dzisiaj do różnych rejonów miejscowości - Kwasówka i Indura do grodzieńskiego, Łunna do mostowskiego, Wierejki, Repla, Wołpa, Roś do wołkowyskiego prawie zawsze były częścią przeważnie powiatu grodzieńskiego guberni grodzieńskiej. Powiat grodzieński istniał w latach 1413-1940, chociaż w ciągu wieków jego granice 
przesuwały się. W roku 1795, po trzecim rozbiorze Rzeczypospolitej, jego zachodnią część włączono w skład państwa pruskiego, a wschodnią - do Imperium Rosyjskiego. Według danych pierwszego spisu ludności z roku 1897 terytorium powiatu grodzieńskiego wynosiło 3770 wiorst kwadratowych, na których mieszkało 206770 osób, w tym Białorusini, Polacy, Żydzi, Litwini, Niemcy, Tatarzy, Rosjanie. W obrębie powiatu znajdowało się jedno miasto (Grodno), 11 miasteczek (wśród nich Wołpa, Indura, Łunna), 955 wsi, folwarków i innych osad chłopskich (Энцььклапедыı, 1993-2001, s. 138). Miasteczko Roś i wieś Repla należały wówczas do powiatu wołkowyskiego. Historia tych miejscowości jest ściśle związana $\mathrm{z}$ historią Polski i jej znakomitymi rodami².

Indura w źródłach pisanych pojawia się na początku XVI w. jako dwór marszałka Wielkiego Księstwa Litewskiego - Jana Dawojnowicza, który w roku 1522 ufundował tu, wraz z założeniem miasteczka, drewniany kościół św. Trójcy. Od drugiej połowy XVI w. po wiek XVII właścicielami Indury byli Kiszkowie, Radziwiłłowie, Pacowie, Wołłowiczowie, Issajkowscy, Mleczkowie, w XVIII w. - Ogińscy, Sołogubowie, Massalscy, w XIX - Brzostowscy, Kozłowscy.

Łunna jest znana od XVI w., kiedy to w roku 1546 królowa Bona ufundowała tu drewniany kościół, w 1785 r. Stanisław August wzniósł świątynię murowaną, którą przebudowano w roku 1895. Miejscowość należała do Waliskich, Czachowskich, Romerów.

Pierwsze wiadomości źródłowe o dworze w Wołpie pochodzą z roku 1449, a o miasteczku Wołpa - z 1517. Kościół został tu założony w XIV w. przez księżnę Holszańską. Odbudowany w roku 1773, był największym drewnianym kościołem na terenie Kresów Wschodnich, a w czasach dzisiejszych to największa drewniana świątynia katolicka na terenie Białorusi z zabytkowym XVI-wiecznym ołtarzem (obecnie w renowacji). W różnych okresach Wołpa należała do wielkich książąt litewskich i królów polskich. Wśród właścicieli miasteczka najbardziej znani są Aleksander Holszański i Lew Sapieha. W roku 1792 miasteczku nadano prawo magdeburskie. W roku 1831 zostało ono Sapiehom skonfiskowane. Historia Wołpy ma wiele sławnych stron wpisanych w historię Rzeczypospolitej, a Eliza Orzeszkowa znalazła tu prototyp Gedalego.

Wzmianki o Rosi pojawiają się w roku 1611 wraz z budową kościoła fundacji Chodkiewiczów. Potem wzniesiono tu pałac, należący począt kowo do hrabiów Potockich, a potem Branickich, $\mathrm{z}$ bogatym archiwum (dzisiaj znajdującym się w Warszawie) i biblioteką. Znajdowały się tu także różne trofea zdobyte w roku 1656 przez Stefana Czarnieckiego.

Kwasówka ma kościół wzniesiony w roku 1626 przez Krzysztofa Wiesołowskiego, marszałka litewskiego. Obecny murowany kościół pochodzi z roku 1871. Miejscowość długo należała do Buchowieckich, jednak od końca XIX w. ostatnim jej właścicielem był Oznabiszyn.

${ }^{2}$ Przy opracowaniu materiału historycznego korzystałam z następujących wydań: Niemcewicz, 1858; Бобровский, 1863; Памятная книжка гродненской губерніи, 1888; Орловский, 1910; Maliszewski, 1919; Карпыза, 2001; Karpyza, 2006-2009; Sorkina, 2007. 
Wierejki należały w XVIII w. do Bispingów, potem do ordynacji massalańskiej. Nowy murowany kościół (w miejsce drewnianego, który spłonął w roku 1762, o czym jest wzmianka w dokumentach parafialnych), został wybudowany w roku $1840 \mathrm{z}$ fundacji Aleksandry, córki Józefa Bispinga, która wyszła za mąż za rosyjskiego generała Aleksandra Świetczyna on właśnie otrzymał od cara pozwolenie na budowę świątyni jako filii kościoła w Repli.

Jedna z pierwszych wzmianek o Repli pochodzi z roku 1558. Czytamy o niej w publikacji Акты Гродненскаго Земскаго Суда (АВАК, 1894, s. 326). W trakcie swego istnienia należała ona do Odachowskich, Jasieńskich, Massalskich, Karpiów, Scypionów, Wołłowiczów. Ostatnimi jej właścicielami byli Zalutyńscy, których bardzo dobrze pamiętają najstarsi okoliczni mieszkańcy ${ }^{3}$. Pierwszy kościół został wybudowany tu w końcu XVI w., kilka razy był odbudowywany wskutek zniszczeń, a ostatni, murowany, neogotycki, wzniesiono w roku 1909.

Wymienione miejscowości, poza Rosią, która od niedawna jest miastem, to obecnie wsie. O ich byłej świetności przypominają tylko ruiny pałaców, dworków i ocalałe kościoły. Ich skład narodowościowy też uległ zmianie wskutek represji, repatriacji, procesów demograficznych i emigracji zarobkowej. Według ostatniego spisu ludności przeprowadzonego w roku 2009, w rejonie grodzieńskim mieszka 18323 Polaków, w wołkowyskim - 18 801, a w mostowskim - $6333^{4}$. Znaczna część mieszkańców o polskim rodowodzie, w tym inteligencja i bogatsi ziemianie, którzy uniknęli wysyłek sowieckich, wyjechała tuż po wojnie. Pozostała przeważnie ludność wiejskiego pochodzenia, co niewątpliwie miało wpływ na dalsze kształtowanie się miejscowej polszczyzny. Należy także brać pod uwagę brak dostępu do polskiego szkolnictwa. Na skutek przymusowej rusyfikacji oraz zupełnej izolacji od terenów etnicznych nastąpiła masowa depolonizacja, a język polski uległ silnej destrukcji (por. Zielińska, 2009, s. 62). Dlatego też właśnie inskrypcje nagrobne są ważnym świadectwem jego funkcjonowania, a jednocześnie pokazują zmiany zachodzące w nim na przestrzeni ubiegłego wieku oraz ostatnich lat.

Na omawianych cmentarzach katolickich na większości nagrobków widnieją inskrypcje napisane po polsku, poczynając od najstarszych pochodzących z końca XVIII w., po współczesne (rok 2013) ${ }^{5}$. Napisy w języku rosyjskim występują znacznie rzadziej, a ich liczebność uzależniona jest od składu etnicznego ludności zamieszkującej okolice. Na wszystkich badanych cmentarzach zanotowano zaledwie kilka inskrypcji w języku białoruskim ${ }^{6}$.

${ }^{3}$ Informatorzy opowiadali mi o nich w trakcie badań.

${ }^{4}$ Materiały Komitetu Statystyki Białorusi: http://www.belstat.gov.by. Dostęp: 10.03.2014. („Национальный статистический комитет Республики Беларусь”, b.d.).

${ }^{5}$ Inaczej jest w środkowej Białorusi, gdzie od lat 40. XX w. inskrypcje najczęściej są pisane po rosyjsku (Werenicz, 2001, s. 171).

${ }^{6}$ Jednokrotne użycie języka białoruskiego w napisach nagrobnych zarejestrowano na Dzierżyńszczyźnie (Werenicz, 2001, s. 171). W inskrypcjach cmentarzy parafii Teolin (pogranicze polsko-białorusko-litewskie) nie ma go w ogóle (Łukuć, 2011, s. 110). 
Ciekawy jest fakt, że nawet jeśli $\mathrm{w}$ dniu pogrzebu z powodu braku znajomości języka polskiego, tablicę informacyjną napisano po rosyjsku, to na pomniku, który według tradycji stawia się rok po śmierci, widnieje napis w języku polskim?7.

W badaniach pominęłam starsze nekropolie miejskie, ponieważ są one (jak na przykład grodzieński cmentarz bernardyński, obecnie zamknięty dla pochówku) raczej cmentarzami historycznymi. Na pomnikach przeważa tu literacka polszczyzna inteligencji miejskiej, o czym świadczą także przykłady ze wspomnianej monografii Jacka Rozmusa i Jerzego Gordziejewa (1999). Natomiast na cmentarzach wiejskich: po pierwsze, widać ciąg tradycji; po drugie, są to cmentarze parafialne, na których chowają zmarłych z okolicznych wsi ${ }^{8}$, co rozszerza teren badań; po trzecie, zebrane $\mathrm{z}$ nich inskrypcje są unikalnym świadectwem miejscowej polszczyzny.

Miejscowości, w których prowadziłam badania, szczególnie dawne miasteczka, od zawsze były wieloetniczne, jednak każda grupa etniczna miała swój cmentarz. Tak więc w miasteczkach Wołpa, Łunna, Indura, Roś były oddzielne cmentarze prawosławny, katolicki i kirkut. Tak pozostało do dzisiaj, tylko społeczność żydowska wskutek Holokaustu została wyłączona z życia miejscowych społeczności, a kirkuty są zaniedbane. We wszystkich pozostałych badanych miejscowościach cmentarze prawosławny i katolicki znajdują się w obrębie jednego ogrodzenia, lecz mają wyraźnie zaznaczone granice. W Wołpie niegdyś dzieliła je wąska ścieżka brukowana, której obecnie już nie ma, a powstały po zniesieniu murów jeden wielki cmentarz został podzielony na części prawosławną i katolicką. Podobny podział występuje także w Wierejkach. W Rosi został niejako wymuszony przez budowę miasteczka wojskowego, którego mur oddziela cmentarz katolicki z zachowaną kaplicą od prawosławnego.

Cmentarze, zwykle porosłe drzewami liściastymi i krzewami, otoczone są murem, przeważnie kamiennym. Niektóre nie mają systemu kolejności w rozmieszczaniu grobów (starsza część cmentarzy w Wołpie i Wierejkach). Inne mają układ dość regularnych ciągów mogił oddzielonych alejkami, który jednak w starszych częściach cmentarza jest prawie nieczytelny (Kwasówka, Indura, Roś). Niemal na wszystkich (z wyjątkiem dwóch) w pobliżu bramy, pośrodku znajduje się kapliczka; w Kwasówce i Indurze - większy krzyż. Groby katolickie na ogół nie mają ogrodzeń - jest to tradycja prawosławna9.

Materiał badawczy - kilkaset inskrypcji, zawierających cechy regionalnej polszczyzny, został ugrupowany według poszczególnych cech polszczyzny kresowej z zaznaczeniem źródła inskrypcji (Indura - In, Wierejki - Wr, Repla - Rp, Roś - Rs, Wołpa - Wp, Łunna - Łn, Kwasówka - Kw).

7 Świadczą o tym krzyże z tablicami, które, według tradycji, jeszcze przez pewien czas leżą obok.

${ }^{8}$ Co ciekawe, na cmentarzach środkowej Białorusi można było chować tylko „swoich” (Werenicz, 2001, s. 170).

9 Podobne spostrzeżenia mają autorzy publikacji o inskrypcjach nagrobnych zarówno na Białorusi (Werenicz, 2001, s. 171; Maryniakowa, 2001, s. 241), jak i na Litwie (Karaś, 2010). 


\section{Sposób identyfikacji osób zmarłych}

Na badanych cmentarzach przeważa polski sposób identyfikacji osób zmarłych: imię i nazwisko: Stanisław Olszewski, Stanisław Kłuniejko, Lucyna Minkiewicz. Kilkadziesiąt razy poświadczono szyk nazwisko i imię: Bergiel Jan, Czynienik Halina. Często spotyka się wspólne groby małżonków: Grigiencza Bronisława i Jurij (In), Pastuszok Waclawa i Włodzimierz (Wr), Stremko Wiktory i Wanda (Rs) i rodzin: rodzina Oleckiewicz (Wr), rodzina Giecołd (Rs), rodzina Szylukowych (Rp) ${ }^{10}$.

Ciekawym zjawiskiem jest poświadczony na stosunkowo nowych pomnikach (po roku 1980, wyjątkowo jeden z lat 50.) szyk wyrazów przy nazywaniu osoby z imieniem odojcowskim, tzw. otczestwem:

Awhustynowicz Stanisław Józefawicz (Wr, 1952), Szoka Józef Adamowicz (In, 1983), Aleksandra Alekseewna Ryszkiel (Wp, 1984), Siwolowski Wiktor Aleksandrowicz (Rp, 1995), Czusziel Kazimierz Iwanowicz (In, 2000), Tyszkiewicz Józef Romowicz (Rs, 2001), Olchowik Józef Domienikowich (Wp, 2001). Rzadziej w miejscu otczestwa w szyku rosyjskim jest umieszczona polska formuła (syn, córka kogo): Ryngel Anna curka Marcina (In, 1987), Sańko Marjanna córka Jana (In, 2006), Malewicka Juzefa córka Jana (In, 2004) albo zmieniony szyk zapisu polskiego: Józef syn Teofila Radziuk (Wp, 1987).

Jest to wynik wpływów tradycji wschodniosłowiańskiej. W tradycji polskiej - i tak jest na większości inwentaryzowanych pomników - utartą formą identyfikacji osoby jest imię i nazwisko. W tradycji rosyjskiej używa się trójczłonowej nazwy: nazwisko, imię i otczestwo. Szyk nazwisko-imię został zarejestrowany 30 razy, a nazwisko-imię-otczestwo - 7. Wieczesław Werenicz (2001, s. 174) uważał, że właśnie stopniowe przenikanie elementów tradycji rosyjskiej w postaci pełnej urzędowej formy nazywania osoby jest ważnym czynnikiem przy wyznaczaniu okresu i stopnia nasilania się wpływów rosyjskich na język ludności polskiej. Biorąc pod uwagę nieliczne zanotowane podobne formy na badanych cmentarzach, można pokusić się o twierdzenie, że na Grodzieńszczyźnie wpływy te pojawiły się dość późno (początek lat 80. XX w.) w porównaniu z innymi regionami Białorusi (por. Kozłowska-Doda, 2000; Werenicz, 2001) i są raczej nieznaczne.

Na wielu pomnikach osób spoza wsi, w której znajduje się cmentarz parafialny, są napisy z podaniem miejscowości, skąd pochodzi zmarły: Prokopowicze, Dychnowicze, Nowosiuki, Długopol, Tupiczany, Krzywonosy, Zamościany, Nacewicze, Siemaszki, Strzelce, Masztalery. Świadczy to o przywiązaniu wagi do miejsca swojego urodzenia ${ }^{11}$.

\footnotetext{
${ }^{10}$ Ogólne nazwisko małżonków i rodzin przeważnie jest tworzone na wzór rosyjski.

${ }^{11}$ Podczas rozmów w trakcie badań często słyszałam od mieszkańców określenie „swoi”, dotyczące wyłącznie tych, którzy się urodzili i mieszkali w danej miejscowości.
} 


\section{Inskrypcje $\mathrm{z}$ informacją o nadawcy}

Większość napisów nagrobnych zawiera informację o nadawcy. Najbardziej rozpowszechniona jest regionalna formuła: Na pamiątkę od... syna, żony (lub inny stopień pokrewieństwa), czasem z wariantami: pamiątka za cała Rodzine, pamiątka rodziców, poświadczona zarówno na terenie Białorusi (Kozłowska-Doda, 2000, s. 116; Maryniakowa, 2001, s. 245; Stelmaczonek, 2002, s. 89; Łukuć, 2011, s. 110), jak i Litwy (Karaś, 2011, s. 102). Najprawdopodobniej jest to kalka z języków wschodniosłowiańskich: ros. На долгую (вечную) память от..., biał. На доўгую (вечную) памяць ад..., ukr. Від дітей $і$ внуків. Informacja о nadawcy bywa też bardziej uszczegółowiona: A najwięcej od syna Edzika (Wp), Syn ich Józef pomnik ten postawił (Rs), Ta pamiątke poświęca St. Zaniewski (In), pamjątka ot Henia i Jani (Wp), pamiątka od wnuka Józefa i curki Antoniny Sienko (In), pamjontka ot Henja (In). Bardzo rzadko nadawca jest wskazany inaczej, np.: $Z$ miłością $w$ sercu pamiętamy - dzieci (In), Tę żałobna pamiątkę poświęcamy pogrążeni w smutku dzieci (In), Tatusiu od córki (In), Kochanej babusi od wnuków (In), Mąż i córki ofiaruja tę pamiątke (Rp), Stroskane rodzice po curce (Kw), a nawet Pamiątnik ustawiony dla męża i siebie (Wr).

Na niektórych nagrobkach wskazany jest rzeźbiarz ${ }^{12}$, czasami może to być krewny zmarłego: wykonat syn Józef (Wp).

Na pomnikach cmentarzy wiejskich, w odróżnieniu od na przykład grodzieńskiego bernardyńskiego, nie ma informacji, kim był zmarły za życia. Dość rzadko są tylko wzmianki o stanie cywilnym: Anufry Siwołowski. Mąż Wiktorii (Rp).

Często na pomnikach podawana jest informacja o tragicznej śmierci ${ }^{13}$ lub że dana osoba została zamordowana, a na jednym jest nawet podany sprawca zbrodni: Został zamordowany przez Karola Józefa (Wp).

Na każdym z badanych cmentarzy znajdują się groby symboliczne: w Repli - urodzonego tu przed wojną a zmarłego w Londynie Zbigniewa Lewczyńskiego; w Wołpie żołnierzy polskich poległych w obronie Ojczyzny w 1920 r.; w Łunnie - krzyż Straży Mogił Polskich i grób zmarłego w łagrach sowieckich Republiki Komi Augustyna Gajdla; w Kwasówce - mieszkańców wsi zamordowanych w 1939 r., w Indurze zamordowanego w roku 1939 Tadeusza Ursyna Niemcewicza i sześciu oficerów Wojska Polskiego, zamordowanych przez bolszewików w roku 1939.

${ }^{12}$ Wśród nich jest Bolesław Szyszkiewicz, wybitny autor wielu pomników grodzieńskiego cmentarza bernardyńskiego, Antoni Rudziński ze Słonimia (są to nagrobki XIX-wieczne, niebrane pod uwagę przy analizie językowej inskrypcji).

13 Taką informację zawierają także nagrobki na Litwie (Karaś, 2011, s. 99). 


\title{
Inskrypcje z inwokacją do osoby zmarłej
}

Na części pomników są dwu- lub czterowersowe formuły o charakterze świeckim $\mathrm{w}$ formie wiersza, mówiące o uczuciach rodziny: bólu i poczuciu utraty ${ }^{14}$.

- Za krótko biło serce Twe drogie // a nam smutek został po Tobie (Kw);

- Nie szumcie bżozy i jeliny // nie przeszkadzajcie spać// dla mojej drogiej rodziny (In);

- Ty odeszła od nas // nie pożegnawszyś z nami // dobry ślad zostawiła // nie zapomnieć latami (Wr);

- Rano opuścił nas... // od tego nasz bul taki, // ze nie sciszyć go kszykiem, // nie wypłakać łzami (Rp);

- Spi coreczko// ma kochana//na krutki czas//byłes dana//spi i czekaj nas (In, 1983).

W nielicznych przypadkach napisy na nagrobkach członków jednej rodziny wygrawerowane są w różnych językach: po polsku i rosyjsku lub po polsku, rosyjsku, białorusku. Na przykład na cmentarzu w Wierejkach w obrębie jednego ogrodzenia są trzy mogiły z inskrypcjami kolejno po białorusku, polsku i rosyjsku: Іван Гаўрылавіч Шаўчук, Аnпа Szеwсzик, Шевчук Анатолий Иванович. Wystawione jeszcze przed rozpoczęciem procesu białorutenizacji Kościoła katolickiego, mogą świadczyć o tym, iż były to rodziny mieszane albo osoby je fundujące nie miały jasno określonej tożsamości narodowej ${ }^{15}$.

Na uwagę zasługują nagrobki ustawione przeważnie po latach 80. XX w., na których informacyjna część inskrypcji jest napisana po polsku, a epitafium po rosyjsku ${ }^{16}$ :

\author{
Czynienik \\ Halina \\ żyla lat 19 \\ pamiatka od \\ rodziny \\ помним любим \\ скорбим
}

(In, brak daty)

${ }_{14}$ Podobne formuły, nowsze, poświadczone są na innych terenach Białorusi (Kozłowska-Doda, 2000, ss. 116-117; Maryniakowa, 2001, s. 246; Łukuć, 2011, s. 113). Na Litwie są rzadkie (Karaś, 2011, s. 102).

${ }^{15}$ Znamienny jest przykład braci Iwanowskich, synów właścicieli majątku Lebiódka Iwanowska między Lidą a Szczuczynem: Jerzy był polskim działaczem społecznym i politykiem; Wacław - wybitnym działaczem odrodzenia białoruskiego, a Tadeusz (Tadas Ivanauskas) - litewskiego.

16 Takie nagrobki są poświadczone także w parafii teolińskiej (Łukuć, 2011, s. 113). 
Wincenty Alchowik

ur. 1.09 .1967

zm. 10.12.2004

Помним, скорбим.

Жена, дочь, родители.

В твои-бы годы жить да жить,

Но смерть безжалостна к годам.

Тебя никем не заменить,

И будешь ть в сердиах всегда.

(Rs, 2004)

Niemała część inskrypcji na badanych cmentarzach, szczególnie z okresu tuż po II wojnie światowej i do końca lat 50. XX w., jest napisana odręcznie, nie w zakładzie, co daje większe prawdopodobieństwo, że jest to żywa mowa, którą się posługiwała miejscowa ludność.

Liczne i bardzo interesujące są cechy regionalne i gwarowe zanotowanych inskrypcji, nasilające się po roku 1945. Agresja Związku Radzieckiego i represje wobec Polaków, przeważnie inteligencji, poskutkowały powolnym zanikiem polszczyzny literackiej na rzecz gwary regionalnej. Tu należy przypomnieć, że w roku 1947 w Grodnie ${ }^{17}$ zamknięto ostatnią polską szkołę, a powszechna przymusowa rusyfikacja i całkowita izolacja od języka ogólnopolskiego przez wiele lat pozbawiły polszczyznę szansy na rozwój. Miejscowa ludność posługiwała się nią tylko w rodzinie lub w Kościele. Najczęściej był to język wyniesiony z domu lub wyuczony w kilku klasach przedwojennej polskiej szkoły. Taka sytuacja miała miejsce do końca lat 80 . i na początku 90. XX w., kiedy wznowiono nauczanie języka polskiego w szkołach i na różnego rodzaju kursach, a młodzież polskiego pochodzenia zaczęła wyjeżdżać na studia w Polsce.

Poniżej zasygnalizuję podstawowe kwestie związane z cechami polszczyzny grodzieńskiej (Bednarczuk, 2010, ss. 75-79, 84-87). Bardziej szczegółowa analiza będzie przedmiotem innego opracowania.

\section{Cechy Polszczyzny północnokresowej w napisach nagrobnych}

\section{Zagadnienia związane z grafią i ortografią}

Funkcjonowanie języka polskiego w otoczeniu wschodniosłowiańskim znajduje odzwierciedlenie w inskrypcjach, gdzie obserwuje się brak znaków diakrytycznych spotszegla (Rs), Wladyslaw (Wp), mieszanie alfabetu polskiego i cyrylicy - dzieci, dyszy (Wp) oraz błędy ortograficzne.

17 W Grodnie od wielu lat istnieje znów wspaniała polska szkoła, wybudowana na koszt państwa polskiego. 
Wskutek syntezy miejscowej wymowy i nieznajomości ortografii oraz grafii polskiej dość często pojawia się różny zapis nazwisk członków tej samej rodziny: Łókasewicz: Łukaszewicz (In), Ryżewski : Ryzheuskaya (Rp), Eriemicz: Eremicz: Jeremicz (Wp), Iezerska: Jesierski (Wp), Bogatyrewicz: Bohatyrevich (Łn), Sliwko : Stiwko (Łn), Dziurdz i Diurć (Kw).

Wpływ rosyjski ujawnia się w pisowni przyimka od (ot syna, ot pszechodnich) (Łn) i przedrostka od- w wyrazach otpocznienie (In), otpoczynek (Łn), por. ros. omdblx.

Spotyka się także archaiczny zapis niektórych imion, który może też być wspierany wpływem rosyjskim: Marja (Wp), Marija (In), Maryia (In), Maryja (In), Marjanna (In) Zofija (Wp, Rp), Emilija (Wp), Henja (Wp), Cypryjan (Rp), Leokadja (Rp).

$\mathrm{W}$ wielu inskrypcjach błędy ortograficzne są wynikiem braku znajomości ortografii polskiej, spowodowanej, jak wspomniałam powyżej, brakiem dostępu do polskiego szkolnictwa i bazowania wyłącznie na polszczyźnie mówionej: kszykiem (Rp), pokuj (Wr), Juzefa (Wp), bul (Rp), wnóczka (Łn), muwi (Rp), curka (Wp), bżozy (In), rzone (Wr), buży (Kw), gożko (Kw), spotszegla (Rs), chszesnej (Rp), kohanej rzonie (Wr), Jólia (In), Żókowska (In), Andżej (In), Gżesik (Wr),Grzegoż (Wp), Kazimierż (Wp), Kazimiesz (Kw, Wp), Adolw (Łn), pamiąntka (In), pamęntka (Wp).

\section{Cechy fonetyczne}

Pisownia wielu inskrypcji (na pewno należy podchodzić do tego bardzo ostrożnie, uwzględniając problemy pisowni) wskazuje na północnokresowe cechy fonetyczne. Niektóre z nich są poświadczone jeszcze w źródłach XVII-XVIII-wiecznych (Kurzowa, 2007, ss. 207-220):

- akanie lub hiperpoprawność: Antanina (Łn), pakój (Rp), Alieksandar (Łn), Władzimierz (Wp), tesćowaj (Wr), smutak (Wp), Antanina (Łn); Włodzisław (Wr);

- wahania $o$ - ó (archaiczna cecha języka polskiego przechowywana na Kresach oraz skutek zderzenia dwóch systemów językowych polskiego i białoruskiego): grob : grób (Rp), pokoj : pokój (Łn);

- ukanie (poświadczone jednorazowo): pokuj ich duschóm (Kw);

- miękkie l': Alieksandar (Łn), Liudwig, liubimyj (Wr), Szyliuk (Rp), Masztaliery (Wp), Maliewska (Kw);

- lw miejsce $ł$ przedniojęzykowego: Jalowczyk (Rp), Wladyslaw (Wp), lzy (In), żyla (Wp);

- wahania spółgłosek twardych - miękkich: pamątka : pamiątka, dzeci : dzieci, rzone : żonie, mienża : męża (liczne przykłady), drogej : drogiej (Wr), Geonefa (Łn);

- palatalność typu kresowego (zmiękczenie przed zwartoszczelinowymi i zwartymi): Frańciszka (Łn), tesćowaj (Rp), Prokopczik (Rp), Adamczik (Rs), Czikałowska (Ln), Czusziel (In); 
- odmienna niż w języku ogólnopolskim dystrybucja spółgłosek miękkich i twardych na skutek jakościowo różnej artykulacji ogólnopolskich spółgłosek palatalnych $s^{\prime}, z^{\prime}, c^{\prime}, d z^{\prime}$ jako półpalatalnych $s^{\prime}, z^{\prime}, c^{\prime}, d z^{\prime}$ : swientej (Rp), abyscie (Wp);

- wahania $u$ - w: Awgustynowicz (Wr);

- dźwięczne krtaniowe $h$ jako rezultat wpływu białoruskiego: Rehina (Wr), Rohaczewski (Wp), Awhustynowicz (In);

- różna realizacja nosówek: rozłożona wymowa zgodna z ogólnopolską: pamjontka (Wp), pamiontka (In, Wr), pamienti (Rp), wstompila (Wp); i różna od ogólnopolskiej: menża (Wr), ziencia (Rp), sonsiada (Rp); denazalizacja: modlimy sie (Wp), za rodzine (In), nad two duszo (Rs).

W znacznej części inskrypcji, przede wszystkim w części informacyjnej, są zapisy, które odzwierciedlają brzmienie danych wyrazów rozpowszechnione na Kresach północno-wschodnich: Geonefa (Kw), Tereza (często), Ejsymont (Rp), Misluk (Rp), Setseiko (Łn), Zdrowaść Maryo (Wp, Rs), Szczelcy 'nazwa miejscowości Strzelce' (Łn).

\section{Cechy gramatyczne}

- odmienny typ odmiany imion męskich: Wiktory (Rs); Apolinar (Rp);

- uogólnienie końcówki -u w C. lp. rzeczowników rodzaju męskiego: Andżeiu (In), tatusiu (Wr), mężu (Wr, Rs), synu (Rs, Kw);

- uogólnienie końcówki -ów w D. lm. rzeczowników: od rodziców, bratów i siostruw (Wp);

- brak końcówek męskoosobowych w nazwiskach małżeństw: tu spoczywaja Wiszniewskie (Wp);

- białoruska końcówka - au w D. lm. rzeczowników: od wnukau (Wr);

- wschodniosłowiańska końcówka -am w C. lmn. rzeczowników: ich duszam (Rp, Łn);

- rosyjskie końcówki w D. lm. rzeczowników: od sioscier i braciew (Rs) (ros. om сестер и братьев); od pszechodnich (Łn) (ros. oт прохожих);

- brak wołacza: zostawiłeś Zbyszek (Rp);

- odmiana rzeczownika po liczebniku złożonym na wzór języka rosyjskiego: $\dot{z y t}$ 31 rok (Wr), por. ros. 31 zod;

- rozkaźnik wzorowany na rosyjskim: spi muj mąż(In); śpicie rodzice (Rs), spi cureczka (In), por. ros. cnu;

- kresowa rekcja czasowników: co jej spotkało (Rp), ulżyj cierpienie (Kw);

- brak końcówek ruchomych w 2 os. czasu przeszłego: ty odeszła, zostawiła (Wr), ty opuścił nas (Rp) albo końcówki pleonastyczne: i tyś miałaś (Kw); 
- częste użycie zakończenia -eś, -em w czasownikach czasu przeszłego w stosunku do osoby płci żeńskiej (poświadczone na kilku cmentarzach): byłeś dana (In), żyłeś niedługo (Łn). Formy te Zofia Kurzowa uważa za innowację morfologiczną powstałą na skutek akania i hiperpoprawnej przed nim ucieczki (Kurzowa, 2007, s. 42);

- formy imiesłowu przysłówkowego uprzedniego: odeszła nie pożegnawszyś (Wr) (może to być kalka z ros.: не попрощавщись lub biał.: не пажагнаўшыся);

- różna realizacja strony zwrotnej czasownika, wspomagana wpływem wschodniosłowiańskim: urodziłsia $(\mathrm{Rp})$ biał. ypadзiўcя, urodiłaś (Rp) ros. poдилась;

- brak kategorii męskoosobowości lub hiperpoprawność: rodzice kochane (Rp), stroskane rodzice $(\mathrm{Kw})$, pogrążeni $w$ smutku dzieci (In);

- konstrukcje z przyimkiem dla + D zamiast ogólnopolskiego celownika: dla mojej drogiej rodziny (In);

- elipsa copuli: nasz bul taki (Rp), jak ciężko żyć (Rs).

W napisach nagrobnych pojawia się również swoista leksyka kresowa:

- rzeczowniki deminiutywne: babusia $(\mathrm{Wr})$;

- zwrócić ('odzyskać', ros. 'вернуть') (Wp).

Dość liczne są też zapożyczenia z rosyjskiego [pomni (Wp), liubimyj (Wr)]. Wśród nich dużą grupę stanowią imiona: Jurij (In), Ivan (Wr), Waliencin (Wr), Edzjk (Wp), Jelena (Wp), Gienadzij (Łn), Sigizmunt (Kw), Genrich (Kw).

Na pomnikach nowszych, postawionych od początku lat 90 . XX w., tj. od momentu początków odrodzenia języka polskiego na Grodzieńszczyźnie (między innymi, wznowienie nauczania języka polskiego, w tym otwarcie polskich szkół) i możliwości swobodniejszych wyjazdów do Polski, zauważalna jest większa poprawność językowa $\mathrm{w}$ napisach nagrobnych.

Nadal jednak dają się w nich zauważyć błędy graficzne i ortograficzne. Mogą one wynikać z niedostatecznej znajomości języka polskiego fundatorów lub nieznajomości alfabetu polskiego wśród kamieniarzy. Najczęściej popełniane błędy to:

- mieszanie dwuznaków: $s z / / c z$ - sposzywa (In), $r z / / c z$ - spożywa (Rp), oddawanie $s z$ jako $s c h$ (z niemieckiego): duschóm (Kw), sh // rz-Kazimesh (Rp), sh // czChmurshik (Rs), cs // cz-Csesław (Wr);

- mieszanie alfabetu lacińskiego i cyrylicy: naмiatka (Wp), sуна (Łn), syнkiem (Wp), pokyj jego dyszy (Rp), drogemu menzy (Rs), dzieci, duszy (Wp); bardzo często obserwuje się wpływ grafii rosyjskiej w pisowni zaimków ego 'jego', emu, 'jemu' (w języku rosyjskim $e$ na początku wyrazu wymawia się jako je);

- stosowanie elementów grafii łacińskiej: Ivan (Łn); 
- mieszanie i // j: pokoi iego duszy (bardzo częste), Iozef(Rp), ustawjony (Wr), jch (Wr), spii w spokoiu (Wr);

- lustrzany zapis drukowanych polskich liter: $z, n, s$ (bardzo często);

- wykorzystanie grafii cerkiewnosłowiańskiej w pisaniu drukowanych liter polskich: (często).

Przedstawiłam najważniejsze i najczęściej spotykane cechy polszczyzny północnokresowej w napisach nagrobnych na Grodzieńszczyźnie. Jest to dopiero wycinek badań nad zgromadzonym materiałem. Z pewnością warto jeszcze zwrócić uwagę na inskrypcje jako komunikat językowy i kulturowy, przeanalizować natężenie wpływów rosyjskich w różnych latach powstawania inskrypcji, zbadać, jaki wpływ na ich język ma postępująca, często wbrew woli wiernych-Polaków, białorutenizacja Kościoła katolickiego. Należałoby także usystematyzować inwentarze poszczególnych cmentarzy. Kontynuacja tych badań jest ważna także ze względu na panującą obecnie $\mathrm{w}$ oficjalnej historiografii białoruskiej tezę o prawie wyłącznie przymusowej polonizacji miejscowej ludności (Смалянчук, 2003, s. 327), która odmawia części społeczności o polskich korzeniach prawa do samookreślenia jako Polacy. Należy podkreślić, że zebrany materiał świadczy o trwaniu tradycji używania języka polskiego na cmentarzach, niezależnie od stanu jego zachowania. Pisane nieraz odręcznie, z odstępstwami od norm ortograficznych, fonetycznych i gramatycznych, przyjętych w języku ogólnopolskim, inskrypcje są żywym świadectwem przywiązania do języka polskiego i troski o zachowanie tradycji mimo procesów rusyfikacji i ateizacji, a także ukazują jedną ze sfer używania języka polskiego w specyficznej sytuacji komunikatywnej na Grodzieńszczyźnie.

\section{Bibliografia}

Bednarczuk, L. (2010). Językowy obraz Wielkiego Księstwa Litewskiego. Kraków: Lexis.

Demski, D. (2000). „Najważniejsze, żeby pamiętać...”. Cmentarz jako źródło do badań tożsamości zbiorowej mieszkańców wsi na Białorusi i ich wyobrażeń na temat śmierci. Etnografia Polska, XLIV(1-2), 79-98.

Grek-Pabisowa, I. (2002). Współczesne gwary polskie na Litwie i Białorusi: fonetyka. Warszawa: sOW.

Jakubowski, J. (1935). Powiat grodzieński w w. XVI (mapa z tekstem). W Prace Komisji Atlasu Historycznego Polski (zeszyt III, ss. 109-114). Kraków: Polska Akademja Umiejętności.

Karaś, H. (2010). Cmentarze na Litwie jako znak wielokulturowego dziedzictwa Wielkiego Księstwa Litewskiego. W J. Mędelska \& Z. Sawaniewska-Mochowa (Red.), Językowe i kulturowe 
dziedzictwo Wielkiego Księstwa Litewskiego (ss. 61-75). Bydgoszcz: Wyd. Uniwersytetu Kazimierza Wielkiego.

Karaś, H. (2011). Uwagi o polskich inskrypcjach nagrobnych na Litwie. W F. Czyżewski, A. Dudek-Szumigaj, \& L. Frolak (Red.), Nekropolie jako znak kultury pogranicza polsko-wschodniosłowiańskiego (ss. 93-105). Lublin: Wydawnictwo Uniwersytetu Marii Curie-Skłodowskiej.

Karpyza, W. (2006-2009). Ziemia wołkowyska (T. 1-4). Lębork: Miejska Biblioteka Publiczna w Lęborku.

Kozłowska-Doda, J. (2000). Język polski napisów cmentarnych z Białorusi środkowej (rejon dzierżyński). W E. Wolnicz-Pawlowska \& W. Szulowska (Red.), Kontakty językowe polszczyny na pograniczu wschodnim (ss. 109-122). Warszawa: Wydawn. Nauk. Semper.

Kurzowa, Z. (2007). Ze studiów nad polszczyzną kresową. Kraków: TAiWPN Universitas.

Łukuć, A. (2011). Cmentarze parafii rzymskokatolickiej Teolin na pograniczu polsko-białoruskim. W F. Czyżewski, A. Dudek-Szumigaj, \& L. Frolak (Red.), Nekropolie jako znak kultury pogranicza polsko-wschodniosłowiańskiego (ss. 107-114). Lublin: Wydawnictwo Uniwersytetu Marii Curie-Skłodowskiej.

Maliszewski, E. (1919). Przewodnik po Gubernji Grodzieńskiej. Warszawa: Wydawnictwo Straży Kresowej.

Maryniakowa, I. (2001). O języku inskrypcji nagrobnych na północnych Kresach. W J. Rieger (Red.), Studia nad polszczyzna kresowa (T. 10, ss. 241-246). Warszawa: „Semper”.

Niemcewicz, J. U. (1858). Podróże historyczne. Paryż: W Księgarni A. Francka; Petersburg: W Księgarni B. M. Wolffa.

Rozmus, J., \& Gordziejew, J. (1999). Cmentarz farny w Grodnie 1792-1939. Kraków: Wydawnictwo Naukowe WSP.

Sorkina, I. (2007). Miasteczka powiatu grodzieńskiego w XIX i na początku XX wieku. Rocznik Grodzieński, 1, 9-34.

Stelmaczonek, A. (2002). Język polski napisów cmentarnych w parafii dryświackiej koło Brasławia. W J. Rieger (Red.) Język mniejszości w otoczeniu obcym (ss. 87-92). Warszawa: Wydawn. Nauk. Semper.

Werenicz, W. (2001). Napisy nagrobne z Kojdanowskiego jako świadectwo stosunków etnicznych, społecznych i wyznaniowych na środkowej Białorusi. W E. Smułkowa \& A. Engelking (Red.), Język i kultura białoruska w kontakcie z sąsiadami: studia poświęcone Antoninie Obrębskiej-Jabłońskiej w stulecie urodzin (ss. 169-186). Warszawa: Wydział Polonistyki Uniwersytetu Warszawskiego.

Zielińska A. (2009). O polszczyźnie szlachty grodzieńskiej. W E. Dzięgiel \& A. Zielińska (Red.), Polszczyzna za granica jako język mniejszości i języki mniejszościowe w Polsce (T. 1, ss. 55-70). Warszawa: Wydawnictwo UKSW.

Акты Гродненскаго Земскаго Суда [АВАК] (1894). (Т. ХХІ). АВАК, Вильна. 
Бобровский, П. (1863). Матеріалы для географіи и статистики Россіи, собранные офицерами генеральнаго штаба (Т. 2). Санкт-Петербургъ: Тип. Э. Веймара.

Дода, Я. (1997). Моўныя асаблівасці надмагільных надпісаў беларуска-літоўскага сумежжа. Весці Міжнароднай Акадэміi вывучэння нацыянальных меншасцей, (2), 34-36.

Карпыза, В. (2001). Гісторыя роду Біспінгаў. Герольд LITHERLAND, (2), 50-51.

Национальный статистический комитет Республики Беларусь (b.d.). Pobrano 22 września 2012, z http://www.belstat.gov.by

Орловский, Е. (1910). Гродненская старина (Ч. 1). Гродно: Губернская типография.

Памятная книжка гродненской губерніи за 1889 год. (1888). Гродно.

Смалянчук, А. (2003). Беларускія палякі або палякі ў Беларусі? W. A. Engelking \& R. Huszcza (Red.), Pogranicza języków, pogranicza kultur (ss. 326-334). Warszawa: Wydział Polonistyki Uniw. Warszawskiego.

Энцыклапедыя гісторыі Беларусі ў 6 т. (1993-2001). (Т. 3). Мінск: Беларуская энцыклапедыя.

\section{Bibliography (transliteration)}

Akty Grodnenskago Zemskago Suda [AВAK] (1894). (Vol. XXI). AVAK, Вильна.

Bednarczuk, L. (2010). Językowy obraz Wielkiego Księstwa Litewskiego. Kraków: Lexis.

Bobrovskiü, P. (1863). Materialy dlia geografii i statistiki Rossii, sobrannye ofitserami general'nago shtaba (Vol. 2). Sankt-Peterburg: Tip. Ė. Veŭmara.

Demski, D. (2000). „Najważniejsze, żeby pamiętać...”. Cmentarz jako źródło do badań tożsamości zbiorowej mieszkańców wsi na Białorusi i ich wyobrażeń na temat śmierci. Etnografia Polska, XLIV(1-2), 79-98.

Doda, IA. (1997). Moŭnyia asablivastsi nadmahil'nykh nadpisaŭ belaruska-litoŭskaha sumezhzha. Vestsi Mizhnarodnaĭ Akademii vyvuchènnia natsyianal'nykh menshastsě̆, (2), 34-36.

Grek-Pabisowa, I. (2002). Współczesne gwary polskie na Litwie i Białorusi: fonetyka. Warszawa: SOW.

Jakubowski, J. (1935). Powiat grodzieński w w. XVI (mapa z tekstem). In Prace Komisji Atlasu Historycznego Polski (zeszyt III, pp. 109-114). Kraków: Polska Akademja Umiejętności.

Karaś, H. (2010). Cmentarze na Litwie jako znak wielokulturowego dziedzictwa Wielkiego Księstwa Litewskiego. In J. Mędelska \& Z. Sawaniewska-Mochowa (Eds.), Językowe i kulturowe dziedzictwo Wielkiego Księstwa Litewskiego (pp.61-75). Bydgoszcz: Wyd. Uniwersytetu Kazimierza Wielkiego.

Karaś, H. (2011). Uwagi o polskich inskrypcjach nagrobnych na Litwie. In F. Czyżewski, A. Dudek-Szumigaj, \& L. Frolak (Eds.), Nekropolie jako znak kultury pogranicza polsko-wschodniosłowiańskiego (pp.93-105). Lublin: Wydawnictwo Uniwersytetu Marii Curie-Skłodowskiej.

Karpyza, V. (2001). Historyia rodu Bispinhaŭ. Herol'd LITHERLAND, (2), 50-51. 
Karpyza, W. (2006-2009). Ziemia wołkowyska (Vols. 1-4). Lębork: Miejska Biblioteka Publiczna w Lęborku.

Kozłowska-Doda, J. (2000). Język polski napisów cmentarnych z Białorusi środkowej (rejon dzierżyński). In E. Wolnicz-Pawlowska \& W. Szulowska (Eds.), Kontakty językowe polszczyny na pograniczu wschodnim (pp. 109-122). Warszawa: Wydawn. Nauk. Semper.

Kurzowa, Z. (2007). Ze studiów nad polszczyzną kresową. Kraków: TAiWPN Universitas.

Maliszewski, E. (1919). Przewodnik po Gubernji Grodzieńskiej. Warszawa: Wydawnictwo Straży Kresowej.

Maryniakowa, I. (2001). O języku inskrypcji nagrobnych na północnych Kresach. In J. Rieger (Ed.), Studia nad polszczyzna kresową (Vol. 10, pp. 241-246). Warszawa: „Semper”.

Natsional'nyı̆ statisticheskiŭ komitet Respubliki Belarus' (n.d.). Retrieved September 22, 2012, from http://www.belstat.gov.by

Niemcewicz, J. U. (1858). Podróże historyczne. Paryż: W Księgarni A. Francka; Petersburg: W Ksieggarni B. M. Wolffa.

Orlovskiı̌, E. (1910). Grodnenskaia starina (Ch. 1). Grodno: Gubernskaia tipografiia.

Pamiatnaia knizhka grodnenskoĭ guberniii za 1889 god. (1888). Grodno.

Rozmus, J., \& Gordziejew, J. (1999). Cmentarz farny w Grodnie 1792-1939. Kraków: Wydawnictwo Naukowe WSP.

Smalianchuk, A. (2003). Belaruskiia paliaki abo paliaki ŭ Belarusi? In A. Engelking \& R. Huszcza (Eds.), Pogranicza języków, pogranicza kultur (ss. 326-334). Warszawa: Wydział Polonistyki Uniw. Warszawskiego .

Sorkina, I. (2007). Miasteczka powiatu grodzieńskiego w XIX i na początku XX wieku. Rocznik Grodzieński, 1, 9-34.

Stelmaczonek, A. (2002). Język polski napisów cmentarnych w parafii dryświackiej koło Brasławia. W J. Rieger (Ed.) Język mniejszości w otoczeniu obcym (pp. 87-92). Warszawa: Wydawn. Nauk. Semper.

Werenicz, W. (2001). Napisy nagrobne z Kojdanowskiego jako świadectwo stosunków etnicznych, społecznych i wyznaniowych na środkowej Białorusi. In E. Smułkowa \& A. Engelking (Eds.), Język i kultura białoruska w kontakcie z sąsiadami: studia poświęcone Antoninie Obrębskiej-Jabłońskiej w stulecie urodzin (pp. 169-186). Warszawa: Wydział Polonistyki Uniwersytetu Warszawskiego.

Zielińska A. (2009). O polszczyźnie szlachty grodzieńskiej. In E. Dzięgiel \& A. Zielińska (Ed.), Polszczyzna za granicą jako język mniejszości i języki mniejszościowe w Polsce (Vol. 1, pp. 55-70). Warszawa: Wydawnictwo UKSW.

Éntsyklapedyia historyi Belarusi ŭ 6 t. (1993-2001). (Vol. 3). Minsk: Belaruskaia èntsyklapedyia. Łukuć, A. (2011). Cmentarze parafii rzymskokatolickiej Teolin na pograniczu polsko-białoruskim. In F. Czyżewski, A. Dudek-Szumigaj, \& L. Frolak (Eds.), Nekropolie jako znak kultury pogranicza polsko-wschodniosłowiańskiego (pp. 107-114). Lublin: Wydawnictwo Uniwersytetu Marii Curie-Skłodowskiej. 


\section{Streszczenie}

Artykuł jest próbą analizy specyfiki regionalnej polszczyzny, zawartej w inskrypcjach nagrobnych z wybranych cmentarzy katolickich na Grodzieńszczyźnie: Kwasówka, Indura, Wierejki, Repla, Łunna, Wołpa, Roś. Autorka przedstawia skrótową informację o miejscowościach, w których odbywały się badania, daje ogólną charakterystykę cmentarzy, a także analizuje polszczyznę inskrypcji nagrobnych, zwracając uwagę na jej cechy regionalne.

Słowa kluczowe: katolickie cmentarze Grodzieńszczyzny; język inskrypcji nagrobnych; polszczyzna grodzieńska

\section{Notes about the Polish language gravestone inscriptions in Grodno region}

\section{Summary}

The article presents the analysis of features of the Polish language displayed in gravestone inscriptions of the chosen Catholic cemeteries of Grodno region - Kvasovka, Indura, Vereyki, Replya, Lunno, Volpa, Ros. The author briefly describes the districts where research was conducted, gives a general characteristics of the cemeteries and analyses the Polish language inscriptions in gravestones, noting regional linguistic features.

Keywords: catholic cemeteries of Grodno region; language of gravestone inscriptions; the Polish language in Grodno region 


\section{Ilustracje}

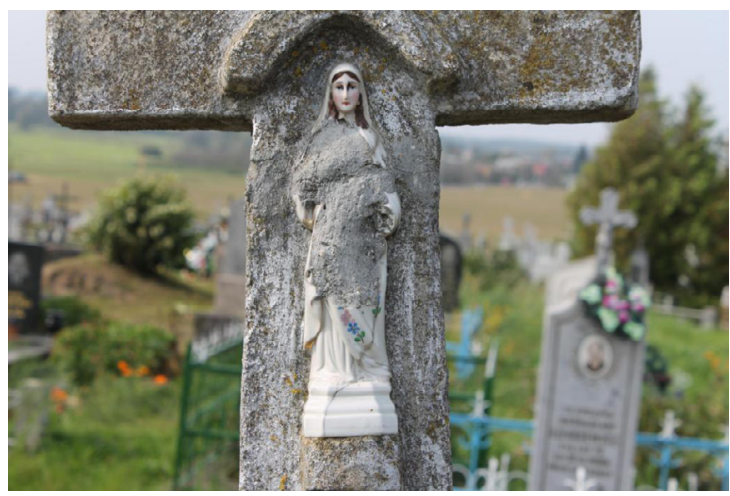

Fot. 1. Krzyż na cmentarzu w Indurze, rok wystawienia nieznany. Fot. Katarzyna Konczewska

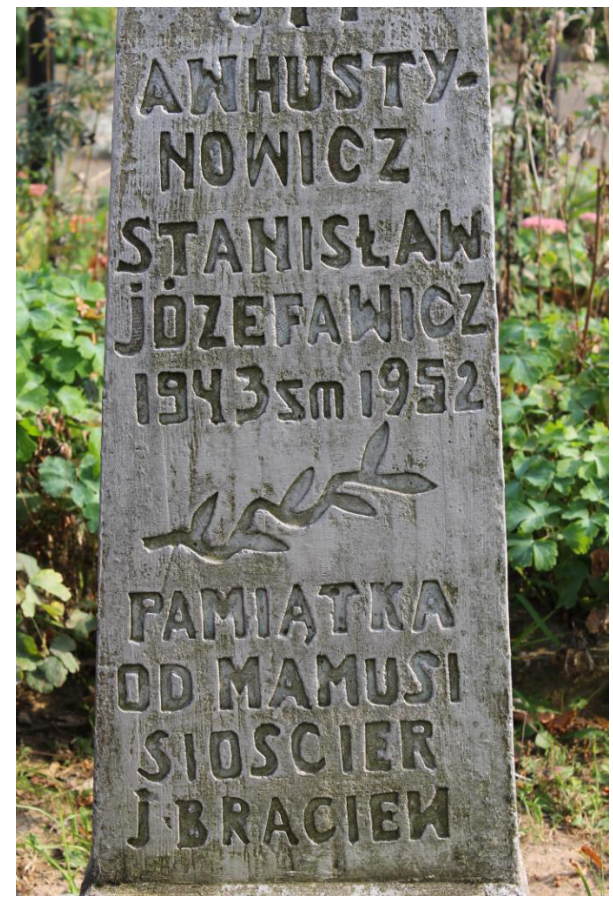

Fot. 2. Inskrypcja nagrobna z cmentarza w Wierejkach. Fot. Katarzyna Konczewska 


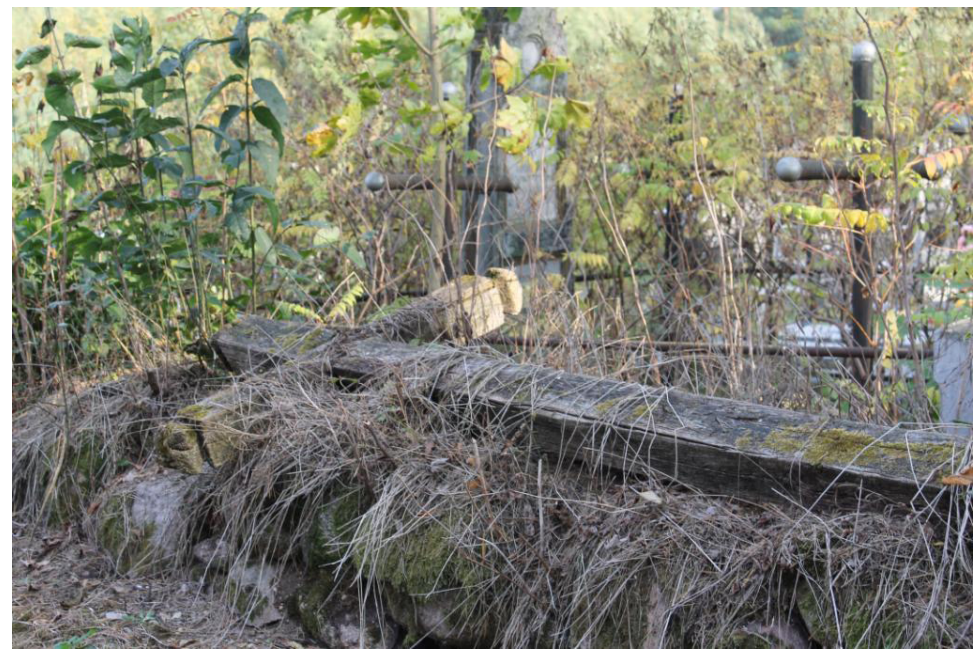

Fot. 3. Krzyż na mogile w starszej części cmentarza w Repli. Fot. Katarzyna Konczewska

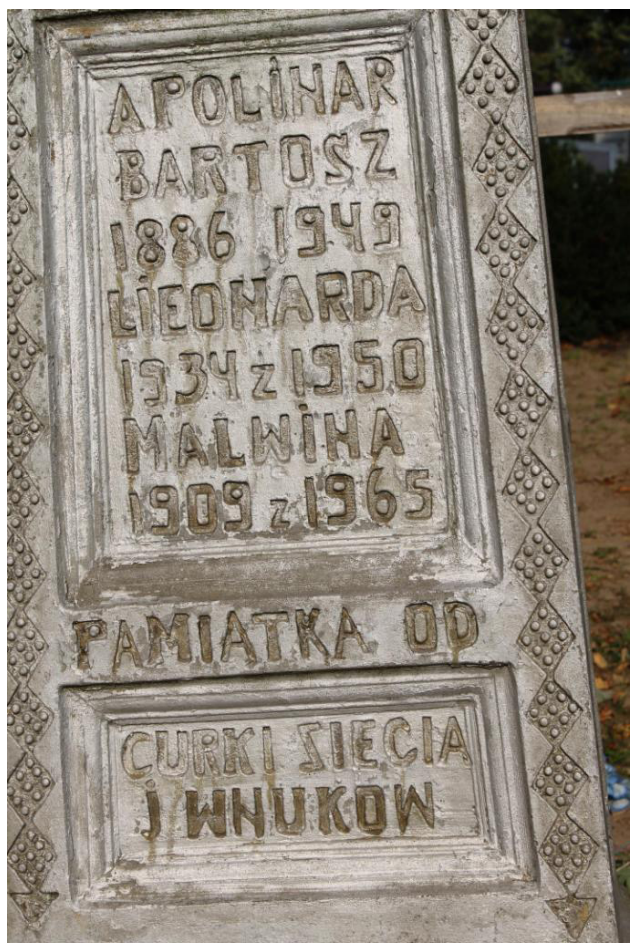

Fot. 4. Inskrypcja nagrobna z cmentarza w Repli. Fot. Katarzyna Konczewska 


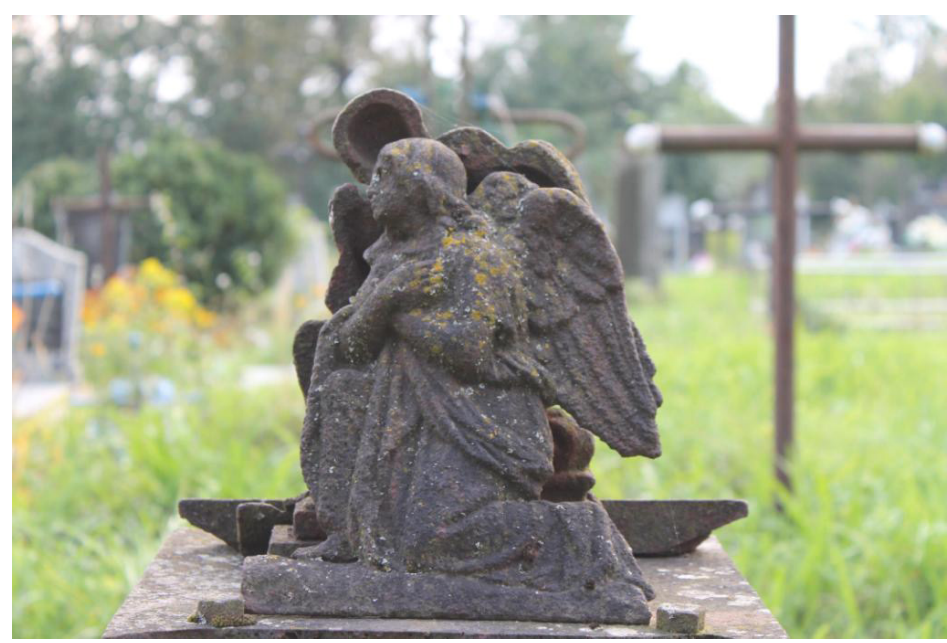

Fot. 5. Fragment pomnika na cmentarzu w Rosi. Fot. Katarzyna Konczewska

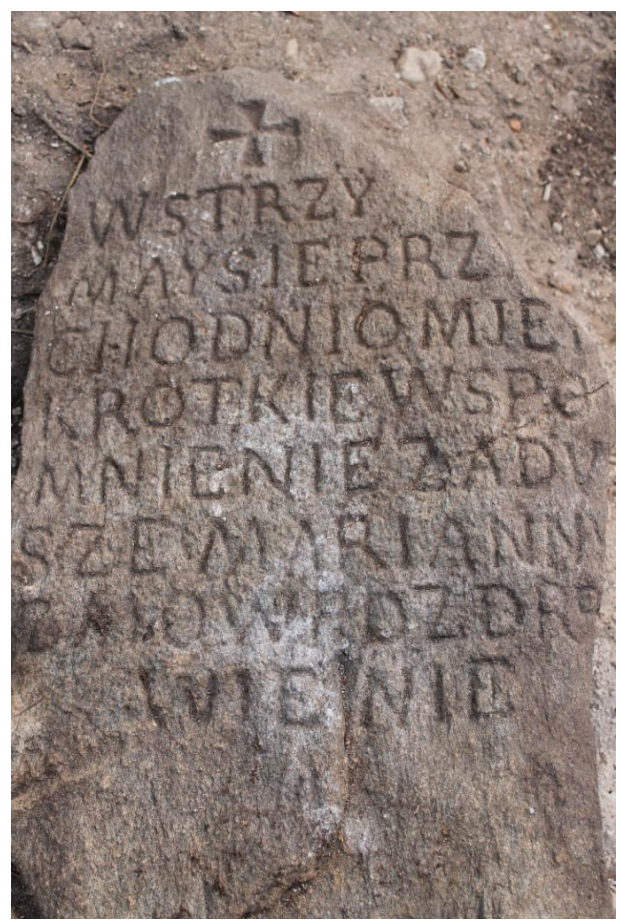

Fot. 6. Wywrócony kamień nagrobny. Starsza część cmentarza w Rosi. Fot. Katarzyna Konczewska 


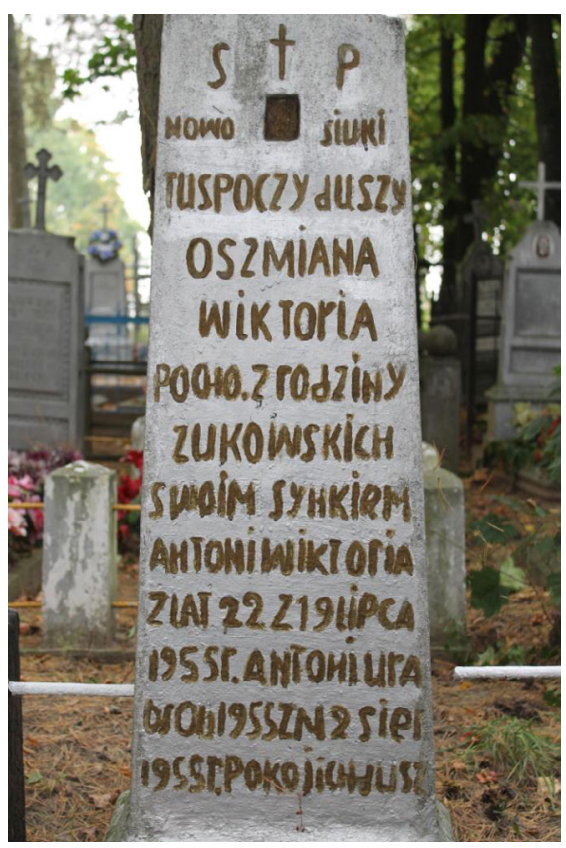

Fot. 7. Inskrypcja nagrobna z cmentarza w Wołpie. Fot. Katarzyna Konczewska

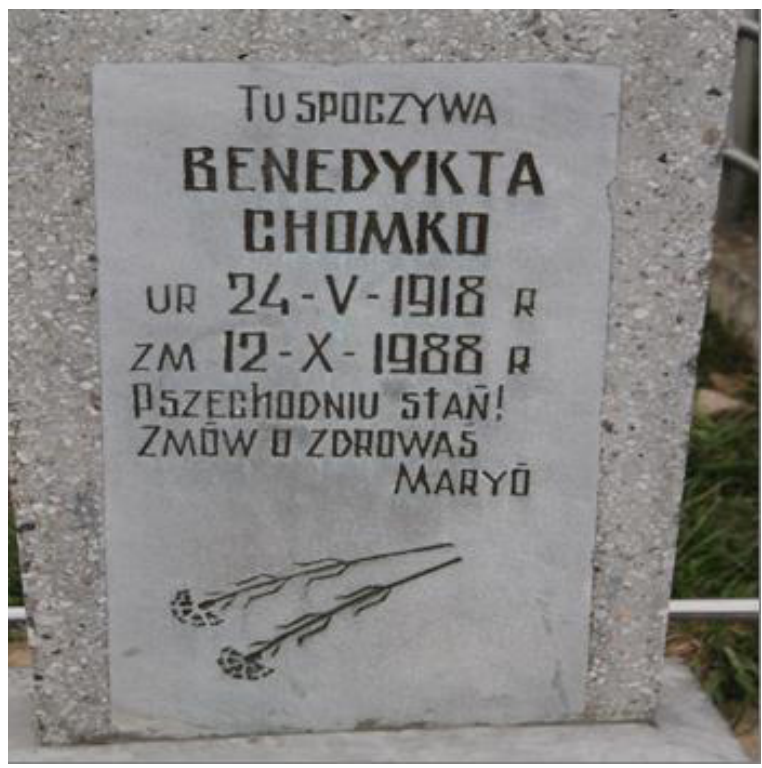

Fot. 8. Inskrypcja nagrobna z cmentarza w Wołpie. Fot. Katarzyna Konczewska 


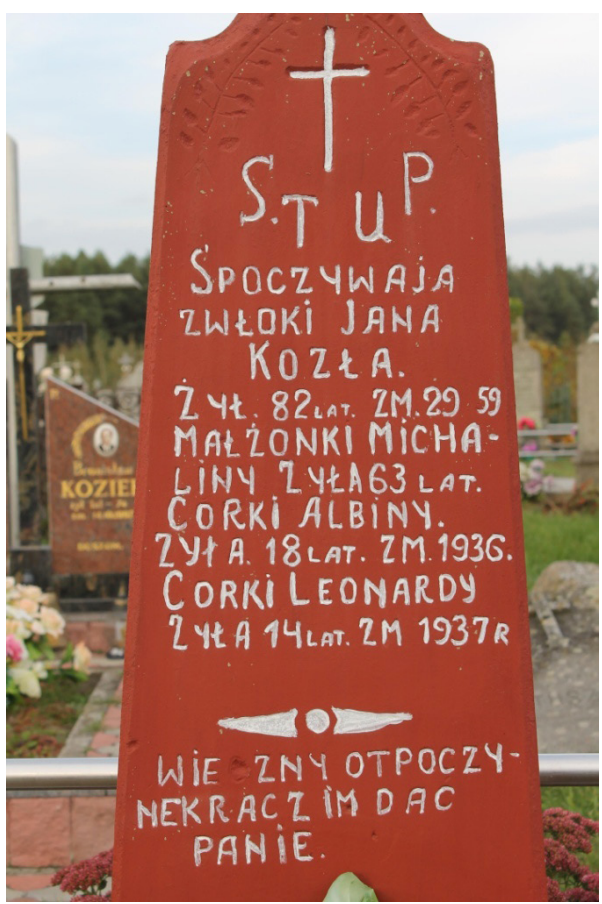

Fot. 9. Inskrypcja nagrobna $\mathrm{z}$ cmentarza w Łunnie. Fot. Katarzyna Konczewska 